\title{
Sensitivity of liver metabolism in jerboa (Jaculus orientalis) to ciprofibrate, a peroxisome proliferator
}

\author{
DRISS MOUNTASSIF ${ }^{1,2}$, MOSTAFA KABINE ${ }^{2}$, KARIMA MOUNCHID $^{3}$, KHADIJA MOUNAJI $^{4}$, \\ NORBERT LATRUFFE ${ }^{1}$ and M'HAMMED SAÏD EL KEBBAJ $^{2}$ \\ ${ }^{1}$ INSERM U 866; Université de Bourgogne, Laboratoire de Biochimie Métabolique et Nutritionnelle, \\ Faculté des Sciences, 21000 Dijon cedex, France; ${ }^{2}$ Laboratoire de Biochimie et Biologie Moléculaire, \\ ${ }^{3}$ Laboratoire d'Histologie et Embryologie and ${ }^{4}$ Laboratoire de Physiologie et Génétique Moléculaire, \\ Université Hassan II - Aïn Chock, Faculté des Sciences, Casablanca, Morocco
}

Received November 5, 2008; Accepted January 8, 2009

\section{DOI: $10.3892 / \mathrm{mmr} 00000143$}

\begin{abstract}
Ciprofibrate is a well-known drug used to normalize lipid parameters and fibrinogen in atherosclerosis patients. In laboratory rodents such as rats or mice, ciprofibrate exhibits peroxisome proliferator activity. However, to date, no clear alterations or side effects caused by ciprofibrate have been noted in humans. In order to further investigate such possible relationships, we studied the effects of sustained ciprofibrate treatment in jerboas (Jaculus orientalis). In these rodents, ciprofibrate does not induce hepatomegaly or promote liver cell DNA replication, confirming that this species more closely resembles humans than do rats or mice. The jerboas were treated daily with ciprofibrate at $3 \mathrm{mg} / \mathrm{kg}$ body weight for 4 weeks. Subcellular markers, clinical enzymes and enzymatic antioxidant defenses were then assessed. The results showed a strong decrease in peroxisomal catalase activity and an increase in the level of malondialdehyde (a stress biomarker). Moreover, ciprofibrate in vivo and in vitro inhibited D-3hydroxybutyrate dehydrogenase, a mitochondrial enzyme of
\end{abstract}

Correspondence to: Dr Norbert Latruffe, INSERM U 866; Université de Bourgogne, Laboratoire de Biochimie Métabolique et Nutritionnelle, Faculté des Sciences, 6 Bd Gabriel, 21000 Dijon cedex, France

E-mail: latruffe@u-bourgogne.fr

Abbreviations: BDH, D-3-hydroxybutyrate dehydrogenase; CPK, creatine phosphokinase; DL-BOH, DL-3-hydroxybutyrate; D-G-3-P, D-glycerol-3-phosphate; EDTA, ethylenediamine tetraacetic acid; GOT, glutamate oxalate transaminase; GPT, glutamate pyruvate transaminase; HDL, high density lipoprotein; KCN, potassium cyanide; LDL, low density lipoprotein; MDA, malondialdehyde; $\mathrm{NAD}(\mathrm{H})$, nicotinamide adenine dinucleotide oxidized (reduced) form; NADPH, nicotinamide adenine dinucleotide phosphate reduced form

Key words: ciprofibrate, Jaculus orientalis, clinical enzymes, antioxidant enzymes, subcellular marker, D-3-hydroxybutyrate dehydrogenase the ketone body interconversion that is important in redox balance $\left(\mathrm{NAD}^{+} / \mathrm{NADH}^{+} \mathrm{H}^{+}\right.$ratio). In conclusion, under these conditions, ciprofibrate induced alterations in the liver oxidative metabolism.

\section{Introduction}

Fibrate drugs have been used pharmacologically to reduce plasma triglycerides and cholesterol. They are among a diverse group of chemicals called peroxisome proliferators, which produce a huge increase in the size and number of peroxisomes in cells. Peroxisome proliferators include plasticizers, herbicides and hypolipidaemic drugs, and are both species- and tissue-specific (rodent liver). A peroxisome is a cell compartment containing enzymes involved in oxidative metabolism $\left(\mathrm{H}_{2} \mathrm{O}_{2}\right.$-producing oxidases, peroxidase/catalase, Mn superoxide dismutase), and is also involved in lipid catabolism via ß-oxidation (1).

Ciprofibrate is one of the basic drugs used to lower risk values of lipid parameters and fibrinogen in atherosclerosis patients (2). The treatment of primates with ciprofibrate leads to an increase in hepatic mitochondria and peroxisomes, without clear evidence of cellular proliferation (3). Notably, El Kebbaj et al (4) revealed that the jerboa (Jaculus orientalis) has unique peroxisome properties in contrast to rats, responding in a moderate manner to peroxisome proliferators such as ciprofibrate and experiencing neither hepatomegaly nor the promotion of liver cell DNA replication. Jerboas are unique nocturnal herbivorous rodents that reside in the subdesert highlands of Morocco. They are an appropriate organism for the study of peroxisome proliferator-activated receptor (PPAR)-dependent metabolic regulation due to their remarkable tolerance to heat and cold and their limited diet, attributed to hibernation (5-8).

The purpose of this study was to elucidate the impact of ciprofibrate on cellular antioxidants, metabolic pathways, and the effects of these on D-3-hydroxybutyrate dehydrogenase $(\mathrm{BDH})$ activity, protein levels and kinetic parameters in mitochondria. To date, no clear alterations or side effects caused by ciprofibrate have been noted in humans. In order to further investigate such possible relationships, we studied the effect 
of sustained ciprofibrate treatment in jerboas. The jerboas were treated daily with ciprofibrate at $3 \mathrm{mg} / \mathrm{kg}$ body weight for 4 weeks. Subcellular markers, clinical enzymes and enzymatic antioxidant defenses were then assessed. The results showed a strong decrease in peroxisomal catalase activity and an increase in the level of malondialdehyde (MDA; a stress biomarker).

Furthermore, we examined the inhibitory effect of ciprofibrate on mitochondrial inner membrane-bound NADdependent BDH (EC. 1.1.1.30) from the liver, which plays an important role in redox balance $\left(\mathrm{NAD}^{+} / \mathrm{NADH}^{+} \mathrm{H}^{+}\right.$ratio) by interconverting aceto-acetate into BDH (9) Any alteration of its activity will affect the energetic metabolism. A catalytic mechanism of the interconversion of $\mathrm{BDH}$ and acetoacetate in both the liver and peripheral tissues has been previously proposed by our group (10). Moreover, this enzyme from the Jerboa has been extensively studied at our laboratory (11-16).

\section{Materials and methods}

Chemicals. Ciprofibrate, or 2-[4-(2,2-dichlorocyclopropyl) phenoloxy]-2-methyl propanoic acid, was a gift from Sanofi Sterling Winthrop (Dijon). DL-3-hydroxybutyrate (DL-BOH; sodium salt) was purchased from Fluka (Buchs, Switzerland); $\mathrm{NAD}^{+}$(free acid) and NADH were from Boehringer (Mannheim, Germany), while succinate and cytochrome c were from Sigma (St. Louis, MO, USA). All other chemicals were of analytical grade.

Animals and administration of ciprofibrate. Adult 4-6 month old jerboas (120-150 g) were captured in the Engil Ait Lahcen region (subdesert East Moroccan highlands) then acclimatized to laboratory conditions for 3 weeks at a temperature of $22^{\circ} \mathrm{C}$ with ad libitum access to food (salad and rat diet) and water. The light cycle during the entire experiment was set to $14 \mathrm{~h}$ light and $10 \mathrm{~h}$ dark. Ciprofibrate was dissolved in $1 \mathrm{ml}$ sterile water and administered daily for 4 weeks by intraperitoneal injection. Four jerboas were administered ciprofibrate $(3 \mathrm{mg} /$ $\mathrm{kg} /$ day), while corresponding groups serving as the control were given sterile water. All experiments were conducted in compliance with the Guide for the Care and Use of Laboratory Animals.

Blood analysis. Determination of total cholesterol, high density lipoprotein (HDL), low density lipoprotein (LDL), triglycerides, creatine phosphokinase (CPK) and transaminases (GOT, glutamate oxalate transaminase; GPT, glutamate pyruvate transaminase) was carried out at the Centre National de Transfusion Sanguine de Casablanca using conventional methods.

Liver mitochondria isolation. The jerboas were decapitated and their livers rapidly removed for mitochondrial extraction according to the method described by Fleischer et al (17), which allows for the preparation of high-yield and pure mitochondrial light fractions. We previously estimated, using marker enzymes, the purity of mitochondria to be $86 \%$ (18).

Biochemical assays. All assays were conducted at $37^{\circ} \mathrm{C}$ with a Jenway $6405 \mathrm{UV} / \mathrm{V}$ isible spectrophotometer, and were carried out using a liver homogenate.
Thiobarbituric acid reactive substances. Lipid peroxidation was estimated by the formation of thiobarbituric acid reactive substances and quantified in terms of MDA equivalents according to the method described by Samokyszyn and Marnett (19).

Liver homogenate sample $(1 \mathrm{ml})$ was added to a $1 \mathrm{ml}$ solution composed of $0.375 \%$ thiobarbituric acid and $15 \%$ trichloracetic acid in $0.25 \mathrm{M}$ hydrochloric acid. The tubes were heated at $100^{\circ} \mathrm{C}$ for $15 \mathrm{~min}$, then cooled on ice to halt the reaction. Centrifugation was conducted at $1000 \mathrm{x} \mathrm{g}$ for $10 \mathrm{~min}$, and the reading of the supernatant was carried out at $535 \mathrm{~nm}$.

Catalase. The consumption of $7.5 \mathrm{mM} \mathrm{H}_{2} \mathrm{O}_{2}$ by peroxisomal catalase in $50 \mathrm{mM}$ potassium phosphate buffer ( $\mathrm{pH} 7.0$ ) was monitored at $240 \mathrm{~nm}$ according to Aebi (20).

Acyl-CoA oxidase. The acyl-CoA oxidase peroxisomal enzyme was assayed according to Lazarow and De Duve (21) under the following conditions: $50 \mathrm{mM}$ phosphate buffer (pH 7.4), 0.2 mM NAD ${ }^{+}, 50 \mu \mathrm{M} \mathrm{FAD}^{+}, 12 \mathrm{mM}$ DTT, $1 \mathrm{mM}$ potassium cyanide $(\mathrm{KCN}), 200 \mu \mathrm{g}$ bovine serum albumin (BSA) and $100 \mu \mathrm{g}$ protein. The mixture was preincubated for $10 \mathrm{~min}$ at $37^{\circ} \mathrm{C}$ before the addition of $50 \mu \mathrm{M}$ of palmitoyl-CoA (Sigma) as a final concentration. Measurement of activity was carried out at $340 \mathrm{~nm}$.

Glutathione reductase. The procedure of Di Ilio et al (22) was used to measure cytosolic glutathione reductase. The assay mixture contained $0.5 \mathrm{mM}$ oxidized glutathione, $1 \mathrm{mM}$ ethylenediamine tetraacetic acid (EDTA), $0.1 \mathrm{mM} \mathrm{NADPH}$ and $50 \mathrm{mM}$ potassium phosphate buffer ( $\mathrm{pH}$ 7.4). NADPH consumption was monitored at $340 \mathrm{~nm}$.

Superoxide dismutase. The Mn-dependent peroxisomal enzyme was assayed according to Paoletti et al (23) under the following conditions: $5 \mathrm{mM}$ EDTA, $2.5 \mathrm{mM} \mathrm{MnCl}_{2}, 0.27 \mathrm{mM}$ $\mathrm{NADH}$ and $3.9 \mathrm{mM}$ 2-mercaptoethanol in $50 \mathrm{mM}$ potassium

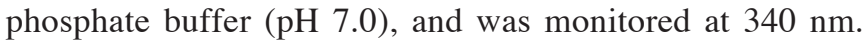
Activity was initiated by the addition of NADH, for a final concentration of $0.27 \mathrm{mM}$.

NADPH-cytochrome c reductase. Endoplasmic reticulumlinked NADPH-cytochrome c reductase was measured as described by Williams and Kamin (24). The reaction mixture, containing $50 \mathrm{mM}$ sodium phosphate buffer ( $\mathrm{pH} 7.7), 1.25 \mathrm{mg} /$ $\mathrm{ml}$ cytochrome c, $0.1 \mathrm{mM}$ EDTA and $100 \mu \mathrm{g}$ protein, was incubated for $2 \mathrm{~min}$ at $37^{\circ} \mathrm{C}$. Subsequently, NADPH at a final concentration of $100 \mu \mathrm{M}$ was added, and the increase in absorbance due to the reduction of cytochrome c was measured.

Glycerol 3-phosphate dehydrogenase. The G3PDH cytosolic enzyme was assayed according to Bentley et al (25) under the following conditions: $100 \mathrm{mM}$ glycine - $\mathrm{NaOH}$ buffer (pH 9.0), $5 \mathrm{mM} \mathrm{NAD}^{+}$and $100 \mu \mathrm{g}$ protein. The mixture was preincubated for $2 \mathrm{~min}$ at $37^{\circ} \mathrm{C}$ before the addition of $5 \mathrm{mM}$ of glycerol-3-phosphate (Sigma) as a final concentration. Activity was recorded at $340 \mathrm{~nm}$.

Glyceraldehyde 3-phosphate dehydrogenase. Cytosolic GAPDH activity was determined by monitoring NADH generation at $340 \mathrm{~nm}$ as described by Serrano et al (26). The $1-\mathrm{ml}$ reaction mixture contained $50 \mathrm{mM}$ Tricine- $\mathrm{NaOH}$ buffer (pH 8.5), $10 \mathrm{mM}$ sodium arsenate, $1 \mathrm{mM} \mathrm{NAD}^{+}$and 2 mM D-G-3-P.

Succinate dehydrogenase. This mitochondrial membranebound enzyme was assayed according to King (27) under the following conditions: $100 \mathrm{mM}$ potassium phosphate buffer (pH 7.4), $0.3 \mathrm{mM}$ EDTA, $0.053 \mathrm{mM}$ dichloroindophenol and 
$100 \mu \mathrm{g}$ of mitochondrial proteins. The mixture was preincubated for $10 \mathrm{~min}$ at $37^{\circ} \mathrm{C}$ before the addition of $50 \mu 1 \mathrm{KCN}$ succinate (containing $3.25 \mathrm{mg} / \mathrm{ml} \mathrm{KCN}$ in $0.5 \mathrm{M}$ succinate). Measurement of activity was carried out at $625 \mathrm{~nm}$.

D-3-hydroxybutyrate dehydrogenase. Mitochondrial BDH activity was measured as described by Lehninger et al (28), following NADH production at $340 \mathrm{~nm}\left(\varepsilon=6.22 \times 10^{3} \mathrm{M}^{-1}\right.$ $\mathrm{cm}^{-1}$ ) using $100 \mu \mathrm{g}$ of frozen/thawed liver mitochondrial protein in a medium containing $6 \mathrm{mM}$ potassium phosphate $(\mathrm{pH} 8.0), 0.5 \mathrm{mM}$ EDTA, $1.27 \%(\mathrm{v} / \mathrm{v})$ redistilled ethanol and $0.3 \mathrm{mM}$ dithiothreitol in the presence of $2 \mathrm{mM} \mathrm{NAD}^{+}$ (Sigma) and $2.5 \mu \mathrm{g}$ rotenone (final addition) to prevent NADH reoxidation by the respiratory chain. The activity was initiated by the addition of DL-BOH (Sigma) to a $10-\mathrm{mM}$ final concentration.

In vitro D-3-hydroxybutyrate dehydrogenase inhibition and kinetic studies. To determine the ciprofibrate concentration of $\mathrm{BDH}$ exhibiting $50 \%$ inhibition $\left(\mathrm{IC}_{50}\right)$, the activities were measured as described previously in the absence and presence of different ciprofibrate concentrations after preincubation for 5 min. The ciprofibrate was added at zero time of incubation. Aliquots were removed at different times during incubation for the measurement of enzymatic activity. Aliquots of the control assay were removed at the same time to calculate the percentage of BDH activity.

For kinetic studies, initial velocities of the enzymatic reaction (in the presence of ciprofibrate concentrations of 0 , $0.15,0.3$ and $0.6 \mathrm{mM}$ ) were performed by varying the concentrations of the substrates: $\mathrm{BOH}(2.5-10 \mathrm{mM})$ or $\mathrm{NAD}^{+}$ (0.5-2 mM). Values for the Michaelis constants $\left(\mathrm{K}_{\mathrm{M}}\right)$, dissociation constants $\left(\mathrm{K}_{\mathrm{D}}\right)$ and maximal velocity for the oxidation of $\mathrm{BOH}$ and the reduction of $\mathrm{NAD}^{+}$by $\mathrm{BDH}$ were obtained by mathematical analysis according to the Cleland method (29).

Western blotting. After SDS-PAGE (12\%) (30) and subsequent transfer to nitrocellulose (31), the mitochondrial proteins $(50 \mu \mathrm{g})$ were exposed to a $1 / 100$ dilution of monospecific rabbit polyclonal anti-BDH anti-rat antibody (32), and detected with the secondary antibody of anti-rabbit IgG peroxidase conjugate (diluted to $1 / 2500$ ) (Promega). The equivalent loaded amount of proteins in each track was controlled by Coomassie blue staining of the overall proteins before and after electrotransfer, as an alternative to possible changes of single housekeeping protein.

Protein assay. Protein content was measured according to the Bradford procedure using BSA as a standard (33).

Statistical data analysis. In each assay, the experimental data represent the mean of four independent assays \pm standard deviation. Means were compared using the Student's t-test. Differences were considered significant at $\mathrm{p}<0.05$ and very significant at $\mathrm{p}<0.01$. Calculation of the inhibition concentrations (IC) was carried out by probit analysis (34).

\section{Results and discussion}

In vivo effect of ciprofibrate on clinical enzymes and lipidic assessment, and on the response of metabolic and stress
Table I. Plasmatic parameters from control and ciprofibratetreated jerboa.

\begin{tabular}{lcc}
\hline & Control & Ciprofibrate \\
\hline Glycemia $(\mathrm{g} / \mathrm{l})$ & $1.25 \pm 0.12$ & $1.19 \pm 0.08$ \\
Triglycerides $(\mathrm{mg} / \mathrm{l})$ & $1.44 \pm 0.46$ & $0.8 \pm 0.297$ \\
Total cholesterol (mg/l) & $1.11 \pm 0.22$ & $1.175 \pm 0.091$ \\
HDL cholesterol (mg/l) & $0.745 \pm 0.063$ & $0.685 \pm 0.077$ \\
LDL cholesterol (mg/l) & $0.185 \pm 0.077$ & $0.22 \pm 0.099$ \\
GOT (U/l) & $159 \pm 5.65$ & $239 \pm 15.5^{\mathrm{a}}(+50 \%)$ \\
GPT (U/l) & $6 \pm 2.24$ & $4 \pm 2.01$ \\
CPK (U/l) & $1143 \pm 280$ & $1067.5 \pm 280.1$ \\
\hline
\end{tabular}

Values represent the means \pm standard deviation from four different jerboas. ${ }^{a} \mathrm{p}<0.05$ (Student's t-test). GOT, glutamate-oxaloacetate transaminase; GPT, glutamate-pyruvate transaminase; CPK, creatine phosphokinase.

biomarkers. Table I indicates that plasma parameters, i.e., glucose, triglycerides and cholesterol (total, HDL and LDL fractions), remained unchanged following ciprofibrate treatment. This confirms that fibrates do not exhibit hypolipidaemic activities under normal lipid homeostasis, doing so only under hyperlipidaemic conditions. However, treatment modified GOT levels $(+50 \%)$, while no significant changes were observed in terms of GPT or CPK activities.

Concerning stress biomarkers, treatment of the jerboa indicated that ciprofibrate induced a significant increase $(+20 \%)$ in the peroxidized lipid level (MDA) and a large decrease in catalase activity $(-58 \%)$ compared with the controls (Table II). The decrease in catalase activity was in agreement with previous results, involving the treatment of jerboa for two weeks at the same ciprofibrate dosage (4). Superoxide dismutase and glutathione reductase activities were decreased, but not in a statistically significant manner.

Regarding the metabolic markers, no changes were observed in peroxisomal acyl-CoA oxidase activity, confirming the lack of, or weak, liver peroxisome proliferation in jerboa (4). Mitochondrial BDH activity was very sensitive to in vivo treatment with ciprofibrate and was strongly decreased (-57\%). This finding is discussed in detail below. No changes were observed in mitochondrial succinate dehydrogenase.

Microsomal NADPH-cytochrome c reductase activity was dramatically decreased (-69\%). A two-week treatment cycle did not significantly modify this activity (4).

No changes were observed regarding cytosolic glycerol3-phosphate dehydrogenase (G3PDH) and glyceraldehyde-3phosphate dehydrogenase (GAPDH).

In order to explore possible correlations between the various biomarkers, principal component analysis was carried out. This method allows for the identification of patterns of data, and expresses the data in a way which highlights their similarities and differences. Fig. 1 shows the existence of one principal group composed of $\mathrm{BDH}$, catalase and NADPHcytochrome c reductase, which explains $62 \%$ of the total variance. All the components of this group exhibited a significant reduction caused by ciprofibrate treatment. Several 
Table II. In vivo effect of ciprofibrate on response of oxidative stress and metabolic biomarkers.

\begin{tabular}{|c|c|c|c|}
\hline Liver markers & Control & Ciprofibrate & \\
\hline Thiobarbituric acid reactive substances (nmol/mg of protein) & $0.29 \pm 0.02$ & $0.35 \pm 0.03^{\mathrm{a}}$ & $(+20 \%)$ \\
\hline Superoxide dismutase ( $\mu \mathrm{mol} / \mathrm{min} / \mathrm{mg}$ of protein $)$ & $5.54 \pm 1.04$ & $4.99 \pm 1.17$ & \\
\hline Glutathione reductase (nmol/min/mg of protein) & $6.95 \pm 0.47$ & $4.77 \pm 0.86$ & \\
\hline Catalase $(\mu \mathrm{mol} / \mathrm{min} / \mathrm{mg}$ of protein $)$ & $0.162 \pm 0.04$ & $0.068 \pm 0.04^{\mathrm{a}}$ & $(-58 \%)$ \\
\hline Acyl-CoA oxidase (nmol/min/mg of protein) & $8.4 \pm 2.4$ & $10.5 \pm 3.2$ & \\
\hline D-3-hydroxybutyrate dehydrogenase (nmol/min/mg of protein) & $0.21 \pm 0.012$ & $0.089 \pm 0.006^{\mathrm{b}}$ & $(-57 \%)$ \\
\hline Succinate dehydrogenase (absorbance/min/mg of protein) & $3.08 \pm 0.43$ & $2.01 \pm 0.38$ & \\
\hline NADPH cytochrome c reductase (nmol/min/mg of protein) & $104 \pm 20$ & $32 \pm 7^{\mathrm{a}}$ & $(-69 \%)$ \\
\hline Glyceraldehyde-3-phosphate dehydrogenase ( $\mu \mathrm{mol} / \mathrm{min} / \mathrm{mg}$ of protein) & $0.53 \pm 0.12$ & $0.58 \pm 0.08$ & \\
\hline Glycerol-3-phosphate dehydrogenase (nmol/min/mg of protein) & $1.13 \pm 0.09$ & $1.40 \pm 0.3$ & \\
\hline
\end{tabular}

Values represent the means \pm standard deviation from four different jerboas. For experimental conditions, see Materials and methods. ${ }^{\mathrm{a}} \mathrm{p}<0.05 ;{ }^{\mathrm{b}} \mathrm{p}<0.01$ (Student's t-test).

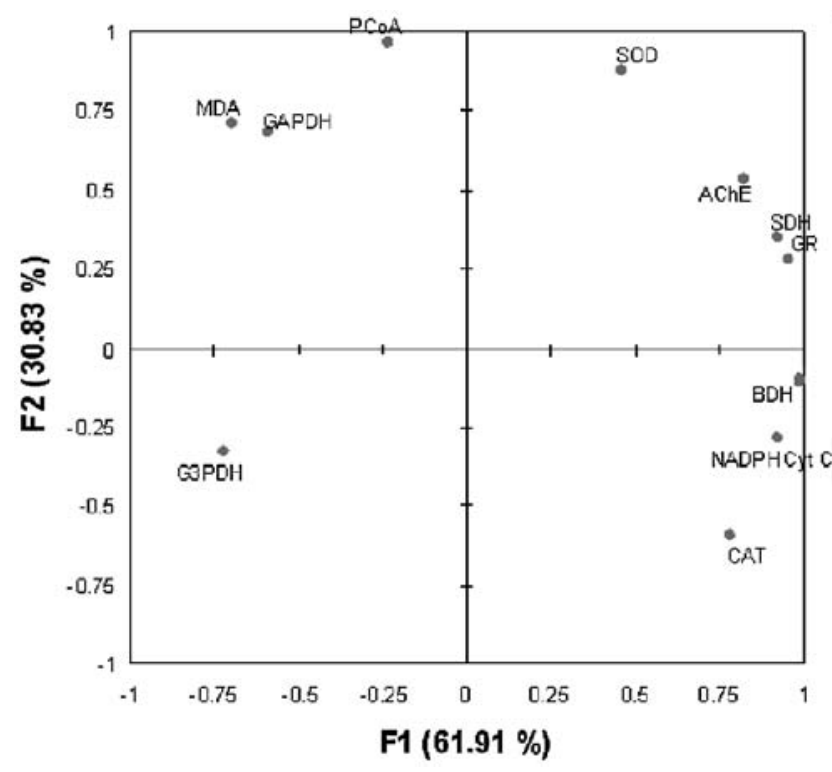

Figure 1. Principal component analysis including all studied parameters.

morphological liver alterations in ciprofibrate-exposed jerboa, such as centrilobular necrotic areas filled by detritis and connective tissue and dilated central veins, were observed (data not shown).

In vivo and in vitro impact of ciprofibrate on D-3hydroxybutyrate dehydrogenase expression and activity. In order to ascertain whether the decrease in BDH activity following in vivo ciprofibrate treatment (Table II) was due to a variation in $\mathrm{BDH}$ protein levels, Western blot analysis was carried out. No decrease in the $\mathrm{BDH}$ immunoreactive band was detected (Fig. 2). This suggests that BDH inhibition was not caused by the inhibition of BDH gene expression at the transcriptional or translational level, but rather was due to the inhibition of BDH catalysis by ciprofibrate. Fig. 3 shows that mitochondrial BDH was sensitive in vitro to the presence of ciprofibrate, and that this sensitivity was dose dependent when

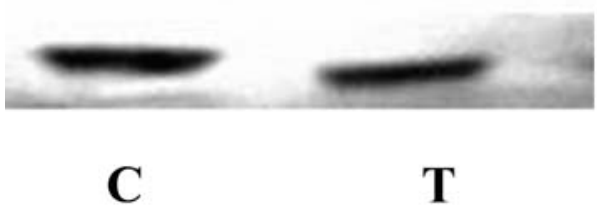

Figure 2. Western blot of the BDH liver mitochondria from control and ciprofibrate-treated jerboas. SDS-PAGE was assayed with $50 \mu \mathrm{g}$ of protein. Lanes $\mathrm{C}$ and $\mathrm{T}$ represent mitochondria extracts from the control and ciprofibrate-treated individual jerboas, respectively. For experimental conditions, see Materials and methods.

the $\mathrm{IC}_{50}$ of $\mathrm{BDH}$ activity was estimated at $0.75 \pm 0.08 \mathrm{mM}$ following probit analysis (34).

The time course of the in vitro inhibition of $\mathrm{BDH}$ by ciprofibrate indicates that BDH is rapidly and strongly inhibited by ciprofibrate in a first order mechanism (data not shown).

The in vitro effects of ciprofibrate on $\mathrm{BDH}$ kinetic parameters were also examined. BDH kinetic parameters $\mathrm{K}_{\mathrm{M}} \mathrm{BOH}$, $\mathrm{K}_{\mathrm{M}} \mathrm{NAD}^{+}, \mathrm{K}_{\mathrm{i} \text { (ciprofibrate vs. } \mathrm{NAD+} \text { ) }}$ and $\mathrm{K}_{\mathrm{i} \text { (ciprofibrate vs. } \mathrm{BOH} \text { ) }}$ are listed in Table III. Notably, it was revealed that the kinetic constants with respect to $\mathrm{NAD}^{+}$and $\mathrm{BOH}$ were modified when $\mathrm{BDH}$ was exposed to ciprofibrate: $\mathrm{K}_{\mathrm{M}} \mathrm{NAD}^{+}$and $\mathrm{K}_{\mathrm{M}} \mathrm{BOH}$ were largely increased (12.3- and 2.2-fold, respectively), indicating a binding of ciprofibrate to the active site. On the other hand, $\mathrm{K}_{\mathrm{i} \text { (ciprofibrate vs. NAD+) }}$ and $\mathrm{K}_{\mathrm{i} \text { (ciprofibrate vs. BOH) }}$ corresponded to 0.128 and $0.820 \mathrm{mM}$ respectively.

Fibrate drugs have been used pharmacologically to prevent cardiovascular diseases by decreasing serum lipid levels. The daily dosage of ciprofibrate is usually $100 \mathrm{mg}(\sim 1.5 \mathrm{mg} / \mathrm{kg} /$ day), a range comparable with the $3 \mathrm{mg} / \mathrm{kg} /$ day amount administered to jerboas in the present study. The hypolipidaemic effect is dependent on PPAR (reviewed in ref. 35). On the other hand, studies have found that prolonged administration of fibrates causes both peroxisome proliferation and cancer in the liver of rodents (36) or, conversely, has proapoptotic effects on hepatoblastoma cell lines (37). Recently, 


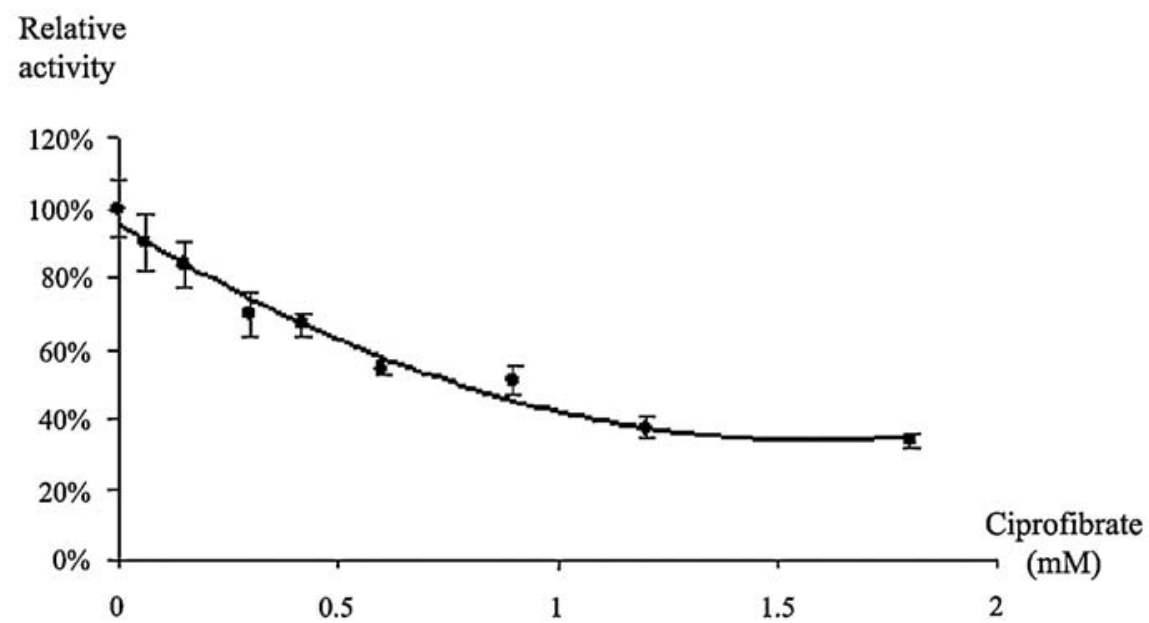

Figure 3. In vitro effect of ciprofibrate concentration on BDH activity. Values represent the means from four individual jerboas. For experimental conditions, see Materials and methods.

Table III. Determination of the kinetic parameters of liver D-3-hydroxybutyrate dehydrogenase in the presence and absence of ciprofibrate.

\begin{tabular}{lcccc}
\hline & Control & \multicolumn{2}{c}{ Ciprofibrate } \\
\hline $\mathrm{K}_{\mathrm{M}} \mathrm{NAD}^{+}(\mathrm{mM})$ & $0.2 \pm 0.01$ & $2.6 \pm 0.28^{\mathrm{a}}$ & (x 12.3) \\
$\mathrm{K}_{\mathrm{i} \text { ciprofibrate vs. NAD+ }}(\mathrm{mM})$ & None & $0.128 \pm 0.01$ & \\
$\mathrm{~K}_{\mathrm{M}}$ BOH $(\mathrm{mM})$ & $1.6 \pm 0.22$ & $3.55 \pm 0.5^{\mathrm{a}}$ & (x 2.2) \\
$\mathrm{K}_{\text {i ciprofibrate vs. BOH }}(\mathrm{mM})$ & None & $0.82 \pm 0.04$ & \\
\hline
\end{tabular}

Experiments used varying concentrations of $\mathrm{NAD}^{+}(0.5,1,1.5$ and $2 \mathrm{mM})$ or $\mathrm{BOH}(2.5,5,7.5$ and $10 \mathrm{mM})$ and ciprofibrate $(0,0.15,0.3$ and $0.6 \mathrm{mM}$ ). Values represent the means \pm standard deviation from four different jerboas. ${ }^{\mathrm{a}} \mathrm{p}<0.01$ (Student's t-test).

Gonzalez and Shah reported a new role of PPAR $\alpha$ in hepatocarcinogenesis in rodents (38), demonstrating that hepatocellular proliferation involves the downregulation of the microRNA let-7c gene by PPAR $\alpha$. Let-7c controls levels of proliferative c-myc by destabilizing its mRNA. Thus, upon suppression of let-7c, c-myc mRNA and protein are elevated, resulting in enhanced hepatocellular proliferation. In contrast, PPAR $\alpha$-humanized mice are resistant to peroxisome proliferator Wy-14,643-induced cell proliferation and cancer, and do not exhibit any downregulation of let-7c gene expression.

Peroxisome proliferation is considered to be a possible link between the overproduction of intracellular $\mathrm{H}_{2} \mathrm{O}_{2}$, a reactive oxygen species, and the initial step involved in carcinogenic mechanisms (39). However, experimental evidence for this adverse effect in humans exposed to these drugs is inconclusive (40). Moreover, the effect of ciprofibrates on oxidative stress induction and prevention has yet to be thoroughly examined, with the exception of a study by Mayer et al, which reported that volunteers exposed to 6-month periods of fenofibrate exhibited elevated levels of oxidized lipoproteins and malondialehyde (41). In order to attempt to verify possible early alterations, we used jerboas, as the response of this species to peroxisome proliferators more closely resembles that of humans than that of rats or mice (4). The present study demonstrated that middle-term treatment with ciprofibrate had several negative side effects, such as alterations in liver tissue (centrilobular necrotic areas), an increase in circulating transaminases (GOT) and oxidative stress modifications, including a strong decrease in peroxisomal catalase activity and an increase in MDA levels. In addition, as previously demonstated in other species (42), ciprofibrate inhibited jerboa mitochondrial BDH at its active site. Since this NAD ${ }^{+}$ dependent enzyme contributes to the body redox balance through the $\mathrm{NAD}^{+} / \mathrm{NADH}^{+} \mathrm{H}^{+}$ratio (42), the direct inhibitory effect of ciprofibrate on this enzyme modifies the redox balance and alters the cascade of cellular functions.

\section{Acknowledgements}

This work was supported by the Regional Council of Burgundy and IFR no. 100, by the 'Programme Thématique d'Appui à la Recherche Scientifique-Morocco, Biologie no. 134' of the 'Action intégrée franco-marocaine MA/05/134', and by the 'European Contract on peroxisomes no. 518 032'.

\section{References}

1. Magalhaes MM and Magalhaes MA: Peroxisomes in adrenal steroidogenesis. Microsc Res Tech 36: 493-502, 1997.

2. Lock EA, Mitchell AM and Elcombe CR: Biochemical mechanisms of induction of hepatic peroxisome proliferation. Annu Rev Pharmacol Toxicol 29: 145-163, 1989.

3. Hoivik DJ, Qualls CW, Mirabile RC, Cariello NF, Kimbrough CL, Colton HM, Anderson SP, Santostefano MJ, Morgan RJ, Dahl RR, Brown AR, Zhao Z, Mudd PN, Oliver WB, Brown HR and Miller RT: Fibrates induce hepatic peroxisome and mitochondrial proliferation without overt evidence of cellular proliferation and oxidative stress in cynomolgus monkeys. Carcinogenesis 25: 1757-1769, 2004.

4. El Kebbaj MS, Cherkaoui Malki M and Latruffe N: Properties of peroxisomes from jerboa (Jaculus orientalis). Eur J Cell Biol 70: 150-156, 1996.

5. Hooper ET and El Hilali M: Temperature regulation and habits in two species of jerboa, genus Jaculus. J Mammal 53: 574-593, 1972.

6. El Hilali M and Veillat JP: Jaculus orientalis: A true hibernator. Mammalia 39: 401-404, 1979. 
7. Amsaguine-Safir S, Bianchi A, Collet P, Huin-Schohn C, Jeanvoine A, Becuwe P, Kremarik-Bouillaud P, Domenjoud L, Keller JM, Schohn H and Dauca M: Induction of the expression of the peroxisome proliferator-activated receptor alpha (PPARalpha) by clofibrate in jerboa tissues. Microsc Res Tech 61: 185-190, 2003.

8. Kabine M, El Kebbaj Z, Oaxaca-Castillo D, Clemencet MC, El Kebbaj MS, Latruffe N and Cherkaoui-Malki M: Peroxisome proliferator-activated receptors as regulators of lipid metabolism; tissue differential expression in adipose tissues during cold acclimatization and hibernation of jerboa (Jaculus orientalis). Biochimie 86: 763-770, 2004

9. Williamson DH, Bates HN, Page MA and Krebs HA: Activities of enzymes involved in acetoacetate utilization in adult mammalian tissues. Biochem J 121: 41-47, 1971.

10. El Kebbaj MS and Latruffe N: Alkylation at the active site of the D-3-hydroxybutyrate dehydrogenase (BDH), a membrane phospholipid-dependent enzyme, by 3-chloroacetyl pyridine adenine dinucleotide (3-CAPAD). Biochimie 79: 37-42, 1997.

11. Cherkaoui-Malki M, Kante A, Demigne C and Latruffe N: Expression of R-3-hydroxybutyrate dehydrogenase, a ketone body converting enzyme in heart and liver mitochondria of ruminant and non-ruminant mammals. Comp Biochem Physiol B 101: 413-420, 1992.

12. El Kebbaj MS, Latruffe $\mathrm{N}$ and Gaudemer Y: Presence of an essential Arginyl residue in D-3-hydroxybutyrate dehydrogenase from mitochondrial inner membrane. Biochem Biophys Res Commun 96: 1569-1578, 1980

13. Kabine M, El Kebbaj MS, Hafiani A, Latruffe N and CherkaouiMalki M: Hibernation impact on the catalytic activities of the mitochondrial D-ß-hydroxybutyrate dehydrogenase in liver and brain tissues of jerboa (Jaculus orientalis). BMC Biochem 4-11, 2003.

14. Latruffe N and Gaudemer Y: Properties and kinetic mechanism of D-3-hydroxybutyrate dehydrogenase from rat liver submitochondrial particles. Comparative effects of different thiol reagents. Biochimie 56: 435-444, 1974.

15. Latruffe N, Brenner SC and Fleischer S: Essential sulfhydryl for reduced nicotinamide adenine dinucleotide binding in D-3hydroxybutyrate dehydrogenase. Biochemistry 19: 5285-5290, 1980.

16. Mountassif D, Kabine M, Latruffe N and El Kebbaj MS: Characterization of two D-beta-hydroxybutyrate dehydrogenase populations in heavy and light mitochondria from jerboa (Jaculus orientalis) liver. Comp Biochem Physiol B Biochem Mol Biol 143: 285-293, 2006.

17. Fleischer S, Mc Intyre JO and Vidal JC: Large-scale preparation of liver mitochondria in high yield. Methods Enzymol 55: 32-39, 1979.

18. Mountassif D, Kabine M, Latruffe N and El Kebbaj MSE: Prehibernation and hibernation effects on the D-3-hydroxybutyrate dehydrogenase of the heavy and light mitochondria from liver jerboa (Jaculus orientalis) and related metabolism. Biochimie 89: 1019-1028, 2007

19. Samokyszyn VM and Marnett LJ: Inhibition of liver microsomal lipid peroxidation by 13-cis-retinoic acid. Free Radic Biol Med 8 : 491-496, 1990

20. Aebi H: Catalase in vivo. Methods Enzymol 105: 121-126, 1984.

21. Lazarow PB and De Duve C: A fatty acyl-CoA oxidizing system in rat liver peroxisomes; enhancement by clofibrate, a hypolipidemic drug. Proc Natl Acad Sci USA 73: 2043-2046, 1976.

22. Di Ilio C, Polidoro G, Arduini A, Muccini A and Federici G: Glutathione peroxidase, glutathione reductase, gluthatione S-transferase and gamma-glutamyl transpeptidase activities in the human early pregnancy placenta. Biochem Med 29: 143-148, 1983.
23. Paoletti F, Aldinucci D, Mocali A and Carparrini A: A sensitive spectrophotometric method for the determination of superoxide dismutase in tissue extracts. Anal Biochem 154: 526-541, 1986.

24. Williams $\mathrm{CH}$ and Kamin $\mathrm{H}$ : Microsomal triphosphopyridine nucleotide-cytochrome c reductase of liver. J Biol Chem 237: 587-595, 1962.

25. Bentley P, Dickinson FM and Jones IG: Purification and properties of rabbit muscle $\alpha$-glycerophosphate dehdrogenase. Biochem J 135: 853-859, 1973.

26. Serrano A, Mateos MI and Losada M: Differential regulation by trophic conditions of phosphorylating and non-phosphorylating $\mathrm{NADP}^{+}$-dependent glyceraldehyde-3-phosphate dehydrogenases in Chlorella fusca. Biochem Biophys Res Commun 181: 1077-1083, 1991.

27. King TE: Preparation of succinate cytochrome c reductase and cytochrome b-cl particles and reconstitution of succinatecytochrorne c reductase. Methods Enzymol 10: 216-225, 1967.

28. Lehninger AL, Sudduth HC and Wise JB: D-3-hydroxybutyric dehydrogenase of mitochondria. J Biol Chem 235: 2450-2455, 1960.

29. Cleland WW: The kinetics of enzymes catalysed reaction with two or more substrates or products. Nomenclature and rate equations. Biochim Biophys Acta 67: 104-137, 1963.

30. Laemmli UK: Cleavage of structural proteins during the assembly of the head of bacteriophage T4. Nature 227: 4668-4673, 1970.

31. Towbin H, Stahelin T and Gordon J: Electrophoretic transfer of proteins from polyacrylamide gels to nitrocel procedure and applications. Biotech 24: 145-149, 1992.

32. Coquard C, Adami P, Cherkaoui Malki M, Fellmann D and Latruffe N: Immunological study of the tissue expression of D-3-hydroxybutyrate dehydrogenase, a ketone body converting enzyme. Biol Cell 181: 381-388, 1987.

33. Bradford M: A rapid and sensitive method for the quantization of microgram quantities of protein utilizing the principle of protein dye binding. Anal Biochem 72: 248-254, 1976.

34. Bliss CI: The calculation of the dosage mortality curve. Ann Appl Biol 22: 134-165, 1935.

35. Paumelle R and Staels B: Cross-talk between statins and PPARalpha in cardiovascular diseases: clinical evidence and basic mechanisms. Trends Cardiovasc Med 18: 73-78, 2008.

36. Reddy JK and Lalwani ND: Carcinogenesis by hepatic peroxisome proliferators: evaluation of the risk of hypolipidemic drugs and industrial plasticizers to humans. Crit Rev Toxicol 12: 1-58, 1983.

37. Canuto RA, Muzio G, Bonelli G, Maggiora M, Autelli R and Barbiero G: Peroxisome proliferators induce apoptosis in hepatoma cells. Cancer Detect Prev 22: 357-366, 1998.

38. Gonzalez FJ and Shah YM: PPARalpha: mechanism of species differences and hepatocarcinogenesis of peroxisome proliferators. Toxicology 246: 2-8, 2008.

39. Diez-Fernandez C, Sanz N, Alvarez AM, Wolf A and Casales M: The effect of non-genotoxic carcinogens, phenobarbital and clofibrate on the relationship between reactive oxygen species antioxidant enzyme expression and apoptosis. Carcinogenesis 19: 1715-1722, 1998.

40. Gonzalez FJ, Peters JM and Cattley RC: Mechanism of action of the nongenotoxic peroxisome proliferator. Role of the peroxisome proliferator-activated receptor alpha. J Natl Cancer Inst 90: 1702-1709, 1998

41. Mayer O Jr, Simon J, Holubec L, Pikner R and Trefil L: Folate co-administration improves the effectiveness of fenofibrate to decrease the lipoprotein oxidation and endothelial dysfunction surrogates. Physiol Res 55: 475-481, 2006.

42. El Kebbaj MS, Cherkaoui Malki M and Latruffe N: Effect of peroxisome proliferators and hypolipemic agents on mitochondrial inner membrane linked D-3-hydroxybutyrate dehydrogenase (BDH). Biochem Mol Biol Intern 35: 65-77, 1995. 